\title{
Glioblastoma: State of the Art and Future Perspectives
}

\author{
Ghazaleh Tabatabai ${ }^{1, *}$ and Hiroaki Wakimoto ${ }^{2, *(\mathbb{D})}$ \\ 1 Interdisciplinary Division of Neuro-Oncology, Hertie Institute for Clinical Brain Research, Center for \\ Neuro-Oncology, Comprehensive Cancer Center Tübingen Stuttgart, University Hospital Tübingen, \\ Eberhard Karls University Tübingen, 72076 Tübingen, Germany \\ 2 Department of Neurosurgery, Massachusetts General Hospital, Harvard Medical School Boston, Boston, \\ MA 02114, USA \\ * Correspondence: ghazaleh.tabatabai@uni-tuebingen.de (G.T.); HWAKIMOTO@mgh.harvard.edu (H.W.)
}

Received: 29 July 2019; Accepted: 30 July 2019; Published: 31 July 2019

check for updates

This special issue is dedicated to glioblastoma and elucidates this disease from different perspectives. Despite multimodal therapies, the prognosis is still dismal. Many features contribute to this therapeutic challenge including high intratumoral and intertumoral heterogeneity, resistance to therapy, migration and invasion, and immunosuppression. With the advent of novel high throughput technologies, significant progress has been made to understand molecular and immunological signatures underlying the pathology of glioblastoma. This special issue aimed at updating researchers on current topics and progress made in basic, preclinical, and clinical glioblastoma research.

The original articles in this special issue present novel findings on molecular mechanisms of radiosensitization, radioresistance and acquired resistance to therapy (Kessler et al., Müller-Längle et al., Shah et al., Llaguno-Munive et al.) [1-4], cell migration (Nowicki et al., Hübner et al.) [5,6], intracellular drug levels (Colin et al.) [7], strategies targeting renewal capacities of cancer stem-like cells (Gravina et al., Sansalone et al., Linder et al.) [8-10], mathematic modeling of synergy, machine learning, deep learning (Kim et al., Hana et al., Wong et al.) [11-13], distinct signaling pathways (Barbagallo et al., Akgül et al., Bensalma et al., Saito et al., Liu et al.) [14-18], prognostic and predictive effects of imaging patterns (Jungk et al., Puig et al.) [19,20], tumor-associated epilepsy (Berendsen et al.) [21], and novel models and experimental therapeutic approaches (Berthier et al., Offenhäuser et al., Privat-Maldonado et al., Lozada-Delgado et al.) [22-25].

Moreover, review articles summarize the current state of knowledge in the fields of platelets (Marx et al.) [26], subventricular zone (Altmann et al.) [27] and microenvironment (Schiffer et al.) [28], lentiviral vectors (Del Vecchio et al.) [29], allergic inflammation (Costanza and Finocchiaro) [30], elderly patients (Minniti et al.) [31], EMT and authophagy (Colella et al.) [32], notch signaling and CXCL12 signaling (Bazzoni et al., Giordano et al.) [33,34], protein phosphatases (Tomiyama et al.) [35], nitric oxide antagonism (Fahey and Girotti) [36], virus-based immunotherapy (Martikainen and Essand; Stepanenko et al.) [37,38], tumor-treating fields (Fabian et al.) [39], amino acid PET (Lohmann et al.) [40], cholesterol metabolism (Ahmad et al.) [41], preclinical modeling (Rominiyi et al.) [42], and EGFR as a therapeutic target (Gao et al.) [43].

It becomes clear that a holistic view from different angles is required to understand this complex disease and discover novel therapeutic targets and biomarkers. We are grateful for all the work the authors have included in this special issue.

Finally, we would like to emphasize the most important perspective, i.e., our patients' perspectives. From their point of view, the main readout for success in patient-centered research is prolonged survival with maintained quality of life. A culture of continued collaboration between disciplines and research teams will be necessary to meet this challenge. 
Conflicts of Interest: Ghazaleh Tabatabai: Personal fees for lectures and advisory board participation from Bristol-Myers-Squibb, AbbVie, Novocure, Medac. Research and travel grants from Bristol-Myers-Squibb, Novocure, Roche Diagnostics, Medac. Member of steering committees of the non-interventional studies TIGER (Novocure) and ONTRk (Bayer). Hiroaki Wakimoto declares no conflict of interest.

\section{References}

1. Kessler, J.; Hohmann, T.; Güttler, A.; Petrenko, M.; Ostheimer, C.; Hohmann, U.; Bache, M.; Dehghani, F.; Vordermark, D. Radiosensitization and a Less Aggressive Phenotype of Human Malignant Glioma Cells Expressing Isocitrate Dehydrogenase 1 (IDH1) Mutant Protein: Dissecting the Mechanisms. Cancers 2019, 11, 889. [CrossRef] [PubMed]

2. Müller-Längle, A.; Lutz, H.; Hehlgans, S.; Rödel, F.; Rau, K.; Laube, B. NMDA Receptor-Mediated Signaling Pathways Enhance Radiation Resistance, Survival and Migration in Glioblastoma Cells-A Potential Target for Adjuvant Radiotherapy. Cancers 2019, 11, 503. [CrossRef] [PubMed]

3. Shah, S.; Rodriguez, G.; Musick, A.; Walters, W.; de Cordoba, N.; Barbarite, E.; Marlow, M.; Marples, B.; Prince, J.; Komotar, R.; et al. Targeting Glioblastoma Stem Cells with 2-Deoxy-D-Glucose (2-DG) Potentiates Radiation-Induced Unfolded Protein Response (UPR). Cancers 2019, 11, 159. [CrossRef] [PubMed]

4. Llaguno-Munive, M.; Romero-Piña, M.; Serrano-Bello, J.; Medina, L.; Uribe-Uribe, N.; Salazar, A.; Rodríguez-Dorantes, M.; Garcia-Lopez, P. Mifepristone Overcomes Tumor Resistance to Temozolomide Associated with DNA Damage Repair and Apoptosis in an Orthotopic Model of Glioblastoma. Cancers 2019, 11, 16. [CrossRef] [PubMed]

5. Nowicki, M.; Hayes, J.; Chiocca, E.; Lawler, S. Proteomic Analysis Implicates Vimentin in Glioblastoma Cell Migration. Cancers 2019, 11, 466. [CrossRef] [PubMed]

6. Hübner, M.; Hinske, C.; Effinger, D.; Wu, T.; Thon, N.; Kreth, F.; Kreth, S. Intronic miR-744 Inhibits Glioblastoma Migration by Functionally Antagonizing Its Host Gene MAP2K4. Cancers 2018, 10, 400. [CrossRef] [PubMed]

7. Colin, M.; Delporte, C.; Janky, R.; Lechon, A.; Renard, G.; Van Antwerpen, P.; Maltese, W.; Mathieu, V. Dysregulation of Macropinocytosis Processes in Glioblastomas May Be Exploited to Increase Intracellular Anti-Cancer Drug Levels: The Example of Temozolomide. Cancers 2019, 11, 411. [CrossRef]

8. Gravina, G.; Mancini, A.; Colapietro, A.; Delle Monache, S.; Sferra, R.; Vitale, F.; Cristiano, L.; Martellucci, S.; Marampon, F.; Mattei, V.; et al. The Small Molecule Ephrin Receptor Inhibitor, GLPG1790, Reduces Renewal Capabilities of Cancer Stem Cells, Showing Anti-Tumour Efficacy on Preclinical Glioblastoma Models. Cancers 2019, 11, 359. [CrossRef]

9. Sansalone, L.; Veliz, E.; Myrthil, N.; Stathias, V.; Walters, W.; Torrens, I.; Schürer, S.; Vanni, S.; Leblanc, R.; Graham, R. Novel Curcumin Inspired Bis-Chalcone Promotes Endoplasmic Reticulum Stress and Glioblastoma Neurosphere Cell Death. Cancers 2019, 11, 357. [CrossRef]

10. Linder, B.; Wehle, A.; Hehlgans, S.; Bonn, F.; Dikic, I.; Rödel, F.; Seifert, V.; Kögel, D. Arsenic Trioxide and (-)-Gossypol Synergistically Target Glioma Stem-Like Cells via Inhibition of Hedgehog and Notch Signaling. Cancers 2019, 11, 350. [CrossRef]

11. Kim, Y.; Lee, J.; Lee, D.; Othmer, H. Synergistic Effects of Bortezomib-OV Therapy and Anti-Invasive Strategies in Glioblastoma: A Mathematical Model. Cancers 2019, 11, 215. [CrossRef] [PubMed]

12. Hana, T.; Tanaka, S.; Nejo, T.; Takahashi, S.; Kitagawa, Y.; Koike, T.; Nomura, M.; Takayanagi, S.; Saito, N. Mining-Guided Machine Learning Analyses Revealed the Latest Trends in Neuro-Oncology. Cancers 2019, 11, 178. [CrossRef] [PubMed]

13. Wong, K.; Rostomily, R.; Wong, S. Prognostic Gene Discovery in Glioblastoma Patients using Deep Learning. Cancers 2019, 11, 53. [CrossRef] [PubMed]

14. Barbagallo, D.; Caponnetto, A.; Brex, D.; Mirabella, F.; Barbagallo, C.; Lauretta, G.; Morrone, A.; Certo, F.; Broggi, G.; Caltabiano, R.; et al. CircSMARCA5 Regulates VEGFA mRNA Splicing and Angiogenesis in Glioblastoma Multiforme Through the Binding of SRSF1. Cancers 2019, 11, 194. [CrossRef] [PubMed]

15. Akgül, S.; Patch, A.; D’Souza, R.; Mukhopadhyay, P.; Nones, K.; Kempe, S.; Kazakoff, S.; Jeffree, R.; Stringer, B.; Pearson, J.; et al. Intratumoural Heterogeneity Underlies Distinct Therapy Responses and Treatment Resistance in Glioblastoma. Cancers 2019, 11, 190. [CrossRef] [PubMed] 
16. Bensalma, S.; Turpault, S.; Balandre, A.; De Boisvilliers, M.; Gaillard, A.; Chadéneau, C.; Muller, J. PKA at a Cross-Road of Signaling Pathways Involved in the Regulation of Glioblastoma Migration and Invasion by the Neuropeptides VIP and PACAP. Cancers 2019, 11, 123. [CrossRef] [PubMed]

17. Saito, N.; Hirai, N.; Aoki, K.; Suzuki, R.; Fujita, S.; Nakayama, H.; Hayashi, M.; Ito, K.; Sakurai, T.; Iwabuchi, S. The Oncogene Addiction Switch from NOTCH to PI3K Requires Simultaneous Targeting of NOTCH and PI3K Pathway Inhibition in Glioblastoma. Cancers 2019, 11, 121. [CrossRef] [PubMed]

18. Liu, H.; Su, Y.; Bamodu, O.; Hueng, D.; Lee, W.; Huang, C.; Deng, L.; Hsiao, M.; Chien, M.; Yeh, C.; et al. The Disruption of the $\beta$-Catenin/TCF-1/STAT3 Signaling Axis by 4-Acetylantroquinonol B Inhibits the Tumorigenesis and Cancer Stem-Cell-Like Properties of Glioblastoma Cells, In Vitro and In Vivo. Cancers 2018, 10, 491. [CrossRef] [PubMed]

19. Jungk, C.; Warta, R.; Mock, A.; Friauf, S.; Hug, B.; Capper, D.; Abdollahi, A.; Debus, J.; Bendszus, M.; von Deimling, A.; et al. Location-Dependent Patient Outcome and Recurrence Patterns in IDH1-Wildtype Glioblastoma. Cancers 2019, 11, 122. [CrossRef]

20. Puig, J.; Biarnés, C.; Daunis-i-Estadella, P.; Blasco, G.; Gimeno, A.; Essig, M.; Balaña, C.; Alberich-Bayarri, A.; Jimenez-Pastor, A.; Camacho, E.; et al. Macrovascular Networks on Contrast-Enhanced Magnetic Resonance Imaging Improves Survival Prediction in Newly Diagnosed Glioblastoma. Cancers 2019, 11, 84. [CrossRef]

21. Berendsen, S.; Spliet, W.; Geurts, M.; Van Hecke, W.; Seute, T.; Snijders, T.; Bours, V.; Bell, E.; Chakravarti, A.; Robe, P. Epilepsy Associates with Decreased HIF-1 $\alpha /$ STAT5b Signaling in Glioblastoma. Cancers 2019, 11, 41. [CrossRef] [PubMed]

22. Berthier, S.; Larrouquère, L.; Champelovier, P.; Col, E.; Lefebvre, C.; Cottet-Rouselle, C.; Arnaud, J.; Garrel, C.; Laporte, F.; Boutonnat, J.; et al. A New Patient-Derived Metastatic Glioblastoma Cell Line: Characterisation and Response to Sodium Selenite Anticancer Agent. Cancers 2019, 11, 12. [CrossRef] [PubMed]

23. Offenhäuser, C.; Al-Ejeh, F.; Puttick, S.; Ensbey, K.; Bruce, Z.; Jamieson, P.; Smith, F.; Stringer, B.; Carrington, B.; Fuchs, A.; et al. EphA3 Pay-Loaded Antibody Therapeutics for the Treatment of Glioblastoma. Cancers 2018, 10, 519. [CrossRef] [PubMed]

24. Privat-Maldonado, A.; Gorbanev, Y.; Dewilde, S.; Smits, E.; Bogaerts, A. Reduction of Human Glioblastoma Spheroids Using Cold Atmospheric Plasma: The Combined Effect of Short- and Long-Lived Reactive Species. Cancers 2018, 10, 394. [CrossRef] [PubMed]

25. Lozada-Delgado, E.; Grafals-Ruiz, N.; Miranda-Román, M.; Santana-Rivera, Y.; Valiyeva, F.; Rivera-Díaz, M.; Marcos-Martínez, M.; Vivas-Mejía, P. Targeting MicroRNA-143 Leads to Inhibition of Glioblastoma Tumor Progression. Cancers 2018, 10, 382. [CrossRef]

26. Marx, S.; Xiao, Y.; Baschin, M.; Splittstöhser, M.; Altmann, R.; Moritz, E.; Jedlitschky, G.; Bien-Möller, S.; Schroeder, H.; Rauch, B. The Role of Platelets in Cancer Pathophysiology: Focus on Malignant Glioma. Cancers 2019, 11, 569. [CrossRef] [PubMed]

27. Altmann, C.; Keller, S.; Schmidt, M. The Role of SVZ Stem Cells in Glioblastoma. Cancers 2019, 11, 448. [CrossRef]

28. Schiffer, D.; Annovazzi, L.; Casalone, C.; Corona, C.; Mellai, M. Glioblastoma: Microenvironment and Niche Concept. Cancers 2019, 11, 5. [CrossRef]

29. Del Vecchio, C.; Calistri, A.; Parolin, C.; Mucignat-Caretta, C. Lentiviral Vectors as Tools for the Study and Treatment of Glioblastoma. Cancers 2019, 11, 417. [CrossRef]

30. Costanza, M.; Finocchiaro, G. Allergic Signs in Glioma Pathology: Current Knowledge and Future Perspectives. Cancers 2019, 11, 404. [CrossRef]

31. Minniti, G.; Lombardi, G.; Paolini, S. Glioblastoma in Elderly Patients: Current Management and Future Perspectives. Cancers 2019, 11, 336. [CrossRef]

32. Colella, B.; Faienza, F.; Di Bartolomeo, S. EMT Regulation by Autophagy: A New Perspective in Glioblastoma Biology. Cancers 2019, 11, 312. [CrossRef]

33. Bazzoni, R.; Bentivegna, A. Role of Notch Signaling Pathway in Glioblastoma Pathogenesis. Cancers 2019, 11, 292. [CrossRef]

34. Giordano, F.; Link, B.; Glas, M.; Herrlinger, U.; Wenz, F.; Umansky, V.; Brown, J.; Herskind, C. Targeting the Post-Irradiation Tumor Microenvironment in Glioblastoma via Inhibition of CXCL12. Cancers 2019, 11, 272. [CrossRef]

35. Tomiyama, A.; Kobayashi, T.; Mori, K.; Ichimura, K. Protein Phosphatases-A Touchy Enemy in the Battle Against Glioblastomas: A Review. Cancers 2019, 11, 241. [CrossRef] 
36. Fahey, J.; Girotti, A. Nitric Oxide Antagonism to Anti-Glioblastoma Photodynamic Therapy: Mitigation by Inhibitors of Nitric Oxide Generation. Cancers 2019, 11, 231. [CrossRef]

37. Martikainen, M.; Essand, M. Virus-Based Immunotherapy of Glioblastoma. Cancers 2019, 11, 186. [CrossRef]

38. Stepanenko, A.; Chekhonin, V. Recent Advances in Oncolytic Virotherapy and Immunotherapy for Glioblastoma: A Glimmer of Hope in the Search for an Effective Therapy? Cancers 2018, 10, 492. [CrossRef]

39. Fabian, D.; Guillermo Prieto Eibl, M.; Alnahhas, I.; Sebastian, N.; Giglio, P.; Puduvalli, V.; Gonzalez, J.; Palmer, J. Treatment of Glioblastoma (GBM) with the Addition of Tumor-Treating Fields (TTF): A Review. Cancers 2019, 11, 174. [CrossRef]

40. Lohmann, P.; Werner, J.; Shah, N.; Fink, G.; Langen, K.; Galldiks, N. Combined Amino Acid Positron Emission Tomography and Advanced Magnetic Resonance Imaging in Glioma Patients. Cancers 2019, 11, 153. [CrossRef]

41. Ahmad, F.; Sun, Q.; Patel, D.; Stommel, J. Cholesterol Metabolism: A Potential Therapeutic Target in Glioblastoma. Cancers 2019, 11, 146. [CrossRef]

42. Rominiyi, O.; Al-Tamimi, Y.; Collis, S. The 'Ins and Outs' of Early Preclinical Models for Brain Tumor Research: Are They Valuable and Have We Been Doing It Wrong? Cancers 2019, 11, 426. [CrossRef]

43. Gao, Y.; Vallentgoed, W.; French, P. Finding the Right Way to Target EGFR in Glioblastomas; Lessons from Lung Adenocarcinomas. Cancers 2018, 10, 489. [CrossRef]

(C) 2019 by the authors. Licensee MDPI, Basel, Switzerland. This article is an open access article distributed under the terms and conditions of the Creative Commons Attribution (CC BY) license (http://creativecommons.org/licenses/by/4.0/). 